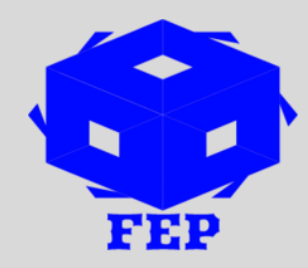

\title{
IS INFORMATION DISCLOSURE SYSTEM IMPROVES MARKET PERFORMANCE? CASE OF INDONESIAN STOCK EXCHANGE \\ Tole Sukino ${ }^{1}$ \\ ${ }^{1}$ Sriwijaya University, Palembang, Indonesia
}

*Corresponding Author: Tole Sukino

Article Received: 25-08-19
Accepted: 03-01-20

Published: 05-02-20

Licensing Details: Author retains the right of this article. The article is distributed under the terms of the Creative Commons Attribution-Non Commercial 4.0 License (http://www.creativecommons.org/licences/by-nc/4.0/) which permits non-commercial use, reproduction and distribution of the work without further permission provided the original work is attributed as specified on the Journal open access page.

\begin{abstract}
Information disclosure prior to opening is implemented by Indonesian stock exchange for improving the pre-market information closure transparency. Based on the policy, information related to the bid/ask volume, five best bid/ask prices, trading volume, and transaction price is disclosed. In this study, investigation is made about the influence of pre-market information on the market quality measures including volatility, liquidity, and trading volume. Intraday day data is collected within the opening of first five minutes or one minute in selected months. Results of the study indicate that pre-market information disclosure transparency is influencing the market quality measures significantly.
\end{abstract}

Keywords: Futures Markets, Market Transparency, Pre-market Transparency, Volume, Liquidity, Volatility

\section{INTRODUCTION}

The function of future market is to provide investors trading and hedging risk function. A crucial topic is to how to reduce market volatility, improve market liquidity, and revitalize the market. If environment is suitable, it can help investors to invest with ease and improve market functioning. In stock market context, information transparency and investor relationship is to obtain investor's trust and improve their confidence and thus improving the business in the stock market. In Indonesian stock exchange, the business is increasing 
keeping in view that Indonesia is an emerging economy. Because of latest systems, new commodities, and market hedging needs, there is some prosperity observed in the market especially the future trading compare to the spot trading. The timing for the future trading session is from 9 am to $2 \mathrm{pm}$; whereas, the stock trading sessions are from 10 am to $3 \mathrm{pm}$. in Indonesian stock exchange, the premarket information disclosure is implemented which means that some of the domestic and foreign market information is accumulated after the trading hours of the previous day and before the market opens for the upcoming day. This premarket information disclosure is improving the pricing efficiency and reducing the bidask spread risk making Indonesian future market system more efficient. Furthermore, since the information about the best five bids are provided before the trading starts, it improves the market efficiency. This situation improves the information transparency which is recommended by several experts and is found to be improving the market trading (Bloomfield \& O'Hara, 1999). A host market in this situation can serve as a communication platform between traders for providing information on asset price and communicating investor's liquidity needs. The rule is that once an order is placed, it cannot be cancelled or modified in order to prevent the human manipulation.

Generally, the information transparency result in an increase of efficiency and fairness in transactions conducted. Based on this situation, investors can easily monitor the trading opportunities and identify their true value and thus have plenty of time for giving response to the market. In this study, the objective is to test the information transparency on the market by testing its effects.

\section{LITERATURE REVIEW}

Market transparency refers to the market participant's ability to obtain information during transactions (O'Hara, 1995). The benefit of information is that it can provide investors the idea about market direction and the real price of the target assets by providing information about order price, trading volume, and strike price. The influence of this information transparency is that such information is quickly reflected on the trading price. Another study by Easley and O'Hara (2004) showed that market information transparency influences the asset pricing. A study by Chen (2009) showed that information transparency improves the market participants access to information and improve market trading. A study by Dia and Pouget (2005), informed traders with liquidity need may rationally disclose their information during the premarket period using the premarket information to reduce their participation cost. This type of trading is labelled as sunshine trading. Quality can be improved by information disclosure related to the volume and price information. Hence, the job of the 
regulating authority is to provide communication platform to traders for communication of such relevant information. In this study, we used the trading volume which is found to be related with price volatility (Wang \& Yau, 2000). Liquidity is about conversion of an asset whether tangible or intangible in to cash. Level of liquidity is partially influenced by whether the transaction of the target can be immediately performed. Higher liquidity is demonstrated in market with higher level of liquidity. A study by Koski and Michaely (2000) showed that the trading time and trading volume improve information asymmetry and under such conditions, market prices tend to be easily influenced by the large amount of transactions. Market quality is also improved under the conditions of information asymmetry and market liquidity.

\section{RESEARCH METHODOLOGY}

The focus of the study is the Indonesian stock exchange market. For testing the information disclosure impact during the premarket period before and after the implementation of this system, the study utilized the intraday data between 1 and 5 minutes after the market opens. The information included are highest price, opening price, trading volume, lowest price, and closing price. The data is obtained from the stock exchange market website and the period is from November 2016 to December 2016. Based on the information, we obtained 240 days information related to the changes in volatility, liquidity, and trading volume. The effects of the study are measured by utilizing the study implementation date as baseline date. For avoiding some problems related to the interrelationship of volatility, liquidity, and trading volume, we utilized some control variables. The analysis of the study is based on using the regression analysis framework.

For measurement of volume, after the market opens, we used the intraday data between 1 and 5 minutes for estimating the difference of trading volume before and after the implementation of information disclosure system which will be referred as event afterwards in this study.

For measuring the liquidity, we adopted the proposed method by Amihud (2002). Accordingly, the intraday data between 1 and 5 minutes after the market opens are used to estimate the difference of liquidity before and after the event. The estimation method used is indicated as follows:

For measuring the volatility, we utilized different methods for estimation. These methods include Garman-Klass estimator, Parkinson estimator, and classic estimator. We used the intraday data between 1 and 5 minutes after the market opens are used for observing the 
difference of three volatility estimations after and after the information disclosure system implemented/event.

\section{FINDINGS}

\section{First Five Minutes after the Market Opens}

The objective of the study was to test the premarket information disclosure system on the market trading business and quality. The information disclosure is about the volume, fivebest bids ask prices, and the opening price of the stock. We investigated the phenomenon 120 days before and 120 days after the implementation of the information disclosure system. The changes in the volatility, liquidity, and trading volume within the first 5 minutes after the market opens. The results are provided in the following table.

Table 1

Statistics for the Futures Market Between 08:45 a.m. and 08:50 a.m

\begin{tabular}{|c|c|c|c|c|}
\hline & & Mean & $t$ value & Wilcoxon rank-sum test \\
\hline Volume & $\begin{array}{l}\text { Before } \\
\text { After }\end{array}$ & $\begin{array}{l}9073.072 \\
7744.719\end{array}$ & $\begin{array}{c}-3.4479 \\
(0.0003 * * *)\end{array}$ & $\begin{array}{c}-4.397 \\
(0.0000 * * *)\end{array}$ \\
\hline Liquidity & $\begin{array}{l}\text { Before } \\
\text { After }\end{array}$ & $\begin{array}{l}1.4409 \\
1.0409\end{array}$ & $\begin{array}{c}3.3414 \\
\left(0.0007^{* * *}\right)\end{array}$ & $\begin{array}{c}2.494 \\
(0.0094 * * *)\end{array}$ \\
\hline Volatility & $\begin{array}{l}\text { Before } \\
\text { After }\end{array}$ & $\begin{array}{l}1.3004 \\
1.9904\end{array}$ & $\begin{array}{c}-1.0144 \\
(0.3107)\end{array}$ & $\begin{array}{c}0.447 \\
(0.4032)\end{array}$ \\
\hline Volatility (Parkinson) & $\begin{array}{l}\text { Before } \\
\text { After }\end{array}$ & $\begin{array}{l}1.4704 \\
1.9704\end{array}$ & $\begin{array}{l}-0.4947 \\
(0.4340)\end{array}$ & $\begin{array}{c}1.424 \\
(0.1437)\end{array}$ \\
\hline Volatility (Garman and Klass) & $\begin{array}{l}\text { Before } \\
\text { After }\end{array}$ & $\begin{array}{l}1.4704 \\
1.7004\end{array}$ & $\begin{array}{l}-0.2399 \\
(0.7123)\end{array}$ & $\begin{array}{c}1.404 \\
(0.1074)\end{array}$ \\
\hline
\end{tabular}

The trading volume before the event was 9073 which decreased to 7744 on average after the event with t value of -3.447 indicating highly significant value. The result shows that after the information disclosure system is implemented, it improved the investors willingness to invest and bringing reduction in information asymmetry. The results are consistent with the findings of Dia and Pouget (2005) who suggest that if traders are well informed, they may use this information for disclosing their trading session for meeting their hedging needs and bringing reduction in the participation cost. The result also shows that market quality is significantly improved after the implementation of the information disclosure system on the basis of volume of trading.

For market liquidity, the average value before the implementation of the information disclosure system was about 1.44 which reduced to 1.04 after the implementation of the system. The t-statistics is 3.34 with highly significant value indicating that the difference is 
statistically significant. The result states that after the implementation of the information disclosure system, the liquidity of the Indonesian stock exchange market is decreased.

For the volatility, the average value is 1.30 which increased to 1.99 after the implementation of information disclosure system with the $t$ value of -1.01 showing insignificant difference. For volatility (Parkinson), the average value before the event is 1.47 which increased to 1.97 but the t-value remains insignificant with value of -0.49 . Finally, the volatility (Garman and Klass) value before the implementation of the information disclosure system is 1.47 and after the event, it increased to 1.70 with t-value of -0.23 which is also insignificant. Thus, we can say that volatility, volatility (Parkinson), and volatility (Garman and Klass) remains insignificantly different before and after the implementation of the information disclosure system.

Table 2

Regression Analysis for the Futures Market from 08:45 a.m. to 8:50 a.m.

\begin{tabular}{|c|c|c|c|c|c|}
\hline & $\begin{array}{c}\text { (1) } \\
\text { Volume }\end{array}$ & $\begin{array}{c}\text { (2) } \\
\text { Illiquidity }\end{array}$ & $\begin{array}{c}(3) \\
\left.\backslash Q^{\wedge}\right]\end{array}$ & $\begin{array}{c}(4) \\
\backslash Q^{\wedge}-a b\end{array}$ & $\begin{array}{c}(5) \\
\backslash Q^{\wedge} \mathrm{cd}\end{array}$ \\
\hline volume - & & & $\begin{array}{l}5.2620 * * * \\
(20.62)\end{array}$ & $\begin{array}{l}4.8820 * * * \\
(20.62)\end{array}$ & $\begin{array}{l}4.8220 * * * \\
(20.23)\end{array}$ \\
\hline Liquidity & & & $\begin{array}{l}24.25 * * * \\
(8.83)\end{array}$ & $\begin{array}{l}8.220 * * * \\
(5.83)\end{array}$ & $\begin{array}{l}6.266 * * * \\
(4.53)\end{array}$ \\
\hline dummy - & $\begin{array}{l}2682.6^{* * * *} \\
(3.65)\end{array}$ & $\begin{array}{l}-4.8608 * * * \\
(-3.36)\end{array}$ & $0.000000255(0.68)$ & $\begin{array}{l}-0.000000226 \\
(-0.63)\end{array}$ & $\begin{array}{l}-0.000000423 \\
(-2.22)\end{array}$ \\
\hline \multirow[t]{2}{*}{ Constant) - } & $\begin{array}{l}6083.2 * * * \\
(20.52)\end{array}$ & $0.000000255^{* * *}(24.84)$ & $\begin{array}{l}-0.00000456 * * * \\
(-8.62)\end{array}$ & $\begin{array}{l}-0.00000338 * * * \\
(-6.62)\end{array}$ & $\begin{array}{l}-0.00000282 * * * \\
(-5.53)\end{array}$ \\
\hline & 0.0530 & 0.0453 & 0.4206 & 0.3528 & 0.3264 \\
\hline $\mathrm{N}$ & 240 & 240 & 240 & 240 & 240 \\
\hline
\end{tabular}

The results of the coefficient tables based on the dummy variables in the first model indicate that there is positive significant improvement observed in the trading volume after the implementation of the information disclosure system in the stock exchange. Furthermore, the second coefficient in the second model is negative which shows that liquidity after the implementation of the system decreased. In third, fourth, and fifth model, the liquidity is controlled and we found positive coefficients which implies that as the trading volume increases, it increases the volatility. 


\section{First Minute after the Market Opens}

Table 3

Statistical Analysis for the Futures Market from 08:45 a.m. to 8:46 am

\begin{tabular}{llccc}
\hline & & Mean & \multicolumn{1}{c}{$\boldsymbol{t}$ value } & Wilcoxon rank-sum test \\
\hline \multirow{2}{*}{ Volume } & Before & 4444.01 & -4.6862 & -4.180 \\
& After & 4180.80 & $(0.0004 * * *)$ & $\left(0.0000^{* * *)}\right.$ \\
Liquidity & Before & 2.2807 & 4.6644 & 2.816 \\
& After & 1.4607 & $(0.0006 * * *)$ & $(0.0048 * * *)$ \\
Volatility & Before & 7.0607 & -0.0816 & 1.442 \\
& After & 7.4007 & $(0.8272)$ & $(0.1482)$ \\
Volatility (Parkinson) & Before & 8.8407 & 0.4107 & 4.161 \\
& After & 8.8607 & $(0.6816)$ & $\left(0.0016^{* * *}\right)$ \\
Volatility (Garman and Klass) & Before & 10.0806 & 0.6484 & 4.780 \\
& After & 8.6007 & $(0.6801)$ & $(0.0002 * * *)$ \\
\hline \multicolumn{2}{c}{$\mathrm{t}$ statistics in parentheses $* \mathrm{p}<0.1, * * \mathrm{p}<0.05, * * * \mathrm{p}<0.01$}
\end{tabular}

The targeted period investigated under this study was reduced to 1 minute for testing the premarket information transparency influence on the market quality in shorter span of time. Results indicate that during the initial 1 minute time span, the volume of trading before the implementation of the information disclosure system was 4444.01 which increased to 4180.80 after the implementation of the system. The t-statistics is -4.68 with higher level of significance level. The liquidity was 2.28 before the implementation of the information disclosure system and afterwards, it decreased to 1.46 with significant t value. The volatility was 7.6 which increased to 7.40 afterwards with $t$-value of -0.08 and insignificant value. The volatility (Parkinson) was 8.84 before the implementation of the system which increased to 8.86 with insignificant t-value. The volatility (Garman and Klass) was 10.08 before the implementation of the information disclosure system which decreased to 8.60 with insignificant t-values. Overall, our results indicate that market quality is improved after the implementation of the information disclosure system.

Table 4

Regression Analysis for the Futures Market from 08:45 a.m. to 8:46 a.m.

\begin{tabular}{|c|c|c|c|c|c|}
\hline & (1) & (2) & (3) & (3) & (5) \\
\hline & Volume & Illiquidity & $\left.\backslash Q^{\wedge}\right]$ & $\mathrm{QQ}^{\wedge} \_\mathrm{ab}$ & $\mathrm{QQ}^{\wedge} \mathrm{cd}$ \\
\hline volume - & & & $\begin{array}{l}3.8010 \text { **** } \\
(8.03)\end{array}$ & $\begin{array}{l}3.6210^{* * * *} \\
(8.85)\end{array}$ & $\begin{array}{l}3.5210^{* * * *} \\
(7.20)\end{array}$ \\
\hline Liquidity & & & $\begin{array}{l}5.813 * * * \\
(8.55)\end{array}$ & $\begin{array}{l}3.158 * * * \\
(6.02)\end{array}$ & $\begin{array}{l}2.085^{* * *} \\
(3.28)\end{array}$ \\
\hline dummy - & $\begin{array}{l}836.8^{* * * *} \\
(3.58)\end{array}$ & $\begin{array}{l}-8.2708^{* * * *} \\
(-3.55)\end{array}$ & $\begin{array}{l}8.8608 \\
(0.33)\end{array}$ & $\begin{array}{l}-0.000000218 \\
(-1.15)\end{array}$ & $\begin{array}{l}-0.000000332 \\
(-1.38)\end{array}$ \\
\hline \multirow[t]{2}{*}{ Constant) - } & $\begin{array}{l}3333.0 * * * \\
(20.03)\end{array}$ & $\begin{array}{l}0.000000228 * * * \\
(13.81)\end{array}$ & $-0.00000228 * * *(-7.26)$ & $\begin{array}{l}-0.00000128 * * * \\
(-3.82)\end{array}$ & $\begin{array}{l}-0.000000888 * * * \\
(-2.77)\end{array}$ \\
\hline & 0.0513 & 0.0503 & 0.3377 & 0.2881 & 0.1881 \\
\hline $\mathrm{N}$ & 230 & 230 & 230 & 230 & 230 \\
\hline
\end{tabular}


Based on the information provided in the table, the first minute after the market opens, the coefficient of the dummy variable in model 1 is positive which shows that trading volume is significantly increased after the implementation of the information disclosure system. When used as dummy variables, the coefficient for liquidity decreased in second model and become negative while in third, fourth, and fifth model, the trading volume and liquidity are controlled and coefficients become positive. This result implies that as the trading volume increases, it also increases the volatility. Volatility is also increased because of higher market liquidity.

According to Table 4, within the first minute after the market opens, the coefficient of the dummy variable in Model (1) is positive, indicating a significant increase of the trading volume after the event. The coefficient of the dummy variable in Model (2) is negative, indicating that illiquidity decreases significantly after the event, which implies the increase of liquidity. In Models (3), (4), and (5), the trading volume and illiquidity are controlled, and the coefficients are positive, indicating that the larger the trading volume is, the higher the volatility. The higher market illiquidity also causes volatility to increase.

\section{First Five Minutes of Trading with Other Factors Considered}

Table 5

Regression Analysis for the Futures Market from 08:45 a.m. to 8:50 a.m.

\begin{tabular}{|c|c|c|c|c|c|}
\hline & $\begin{array}{c}\text { (1) } \\
\text { Volume }\end{array}$ & $\begin{array}{c}\text { (2) } \\
\text { Liquidity }\end{array}$ & $\begin{array}{c}(3) \\
\left.\backslash \mathbf{Q}^{\wedge}\right]\end{array}$ & $Q^{\wedge}{ }^{(4)} \cdot a b$ & $\begin{array}{c}(5) \\
\backslash Q^{\wedge} \mathrm{cd}\end{array}$ \\
\hline volume - & & & $\begin{array}{c}5.4410 * * * \\
(10.58)\end{array}$ & $\begin{array}{c}4.8410 * * * \\
(10.46)\end{array}$ & $\begin{array}{c}.8110^{* * * *} \\
(8.81)\end{array}$ \\
\hline Liquidity & & & $\begin{array}{c}14.48 * * * \\
(8.84)\end{array}$ & $\begin{array}{c}8.145^{* * * *} \\
(5.88)\end{array}$ & $\begin{array}{c}8.158 * * * \\
(4.46)\end{array}$ \\
\hline dummy - & $\begin{array}{c}1881.4 * * * \\
(3.68)\end{array}$ & $\begin{array}{c}-4.88 \mathrm{e}-08 * * * \\
(-3.36)\end{array}$ & $\begin{array}{c}0.000000450 \\
(0.68)\end{array}$ & $\begin{array}{c}-0.000000440 \\
(-0.61)\end{array}$ & $\begin{array}{c}-0.000000404 \\
(-1.08)\end{array}$ \\
\hline S\&P - & $\begin{array}{c}-101484.3 * * * \\
(-4.85)\end{array}$ & $\begin{array}{c}-0.000000488 \\
(-0.46)\end{array}$ & $\begin{array}{c}0.0000138 \\
(0.53)\end{array}$ & $\begin{array}{c}-0.0000185 \\
(-0.83)\end{array}$ & $\begin{array}{c}-0.0000310 \\
(-1.18)\end{array}$ \\
\hline $\begin{array}{c}\text { Constant) } \\
-\end{array}$ & $\begin{array}{c}8144.1 * * * \\
(40.88) \\
0.0865\end{array}$ & $\begin{array}{c}0.000000155^{* * *} \\
(14.80) \\
0.0456\end{array}$ & $\begin{array}{c}-0.00000464 * * * \\
(-8.65) \\
0.4113\end{array}$ & $\begin{array}{c}-0.00000331 * * * \\
(-6.36) \\
0.3533\end{array}$ & $\begin{array}{c}-0.00000480 * * * \\
(-5.44) \\
0.3405\end{array}$ \\
\hline $\mathrm{N}$ & 240 & 240 & 240 & 240 & 240 \\
\hline
\end{tabular}

The results for the coefficient table shows that the dummy variable had positive coefficient in model 1 which shows that trading volume in the first 5 minutes of the trading had positive and significant influence by the information disclosure system in the selected stock exchange. The coefficient for the S\&P500 is negative shows that the Indonesian stock exchange market is negatively correlated with the US stock market. One reason for this situation is that during the study market, the stock market behavior was bull behavior making investors to invest more in the stock exchange. However, with the reduction in the hedge ratio, the trading 
volume in future markets declined due to the crowding-out effects. The dummy variable in model 2 shows negative significant relationship showing the liquidity after the event is increased with no significant influence on market liquidity. Liquidity and volume are control variable in third, fourth, and fifth model and shows positive relationship indicating higher volatility and trading volume relationship.

\section{First Minute of Trading with Other Factors Considered}

Table 6

Regression Analysis of the Futures Market from 08:45 a.m. to 8:46 a.m.

\begin{tabular}{|c|c|c|c|c|c|}
\hline & $\begin{array}{c}\text { (1) } \\
\text { Volume }\end{array}$ & $\begin{array}{c}(2) \\
\text { Liquidity }\end{array}$ & $\begin{array}{c}(3) \\
\left.\backslash \mathbf{Q}^{\wedge}\right]\end{array}$ & $Q^{\wedge}{ }^{(5)} \cdot a b$ & $\begin{array}{c}(5) \\
\backslash Q^{\wedge} \mathrm{cd}\end{array}$ \\
\hline volume - & & & $\begin{array}{l}5.8810 * * * \\
(7.85)\end{array}$ & $\begin{array}{l}5.5510 * * * \\
(8.77)\end{array}$ & $\begin{array}{l}5.5210 * * * \\
(7.01)\end{array}$ \\
\hline Liquidity & & & $\begin{array}{l}5.811 * * * \\
(8.53)\end{array}$ & $\begin{array}{l}3.153 * * * \\
(7.00)\end{array}$ & $\begin{array}{c}2.073 * * * \\
(3.27)\end{array}$ \\
\hline dummy - & $\begin{array}{c}853.7 * * * \\
(3.58)\end{array}$ & $\begin{array}{c}-8.2708 * * * \\
(-3.55)\end{array}$ & $\begin{array}{c}8.8108 \\
(0.55)\end{array}$ & $\begin{array}{c}-0.000000217 \\
(-1.15)\end{array}$ & $\begin{array}{c}-0.000000338 \\
(-1.57)\end{array}$ \\
\hline S\&P - & $\begin{array}{c}-27383.8 \\
(-1.73)\end{array}$ & $\begin{array}{c}8.58 \mathrm{e}-08 \\
(0.05)\end{array}$ & $\begin{array}{c}-0.00000277 \\
(-0.18)\end{array}$ & $\begin{array}{c}-0.0000177 \\
(-1.35)\end{array}$ & $\begin{array}{c}-0.0000233 \\
(-1.57)\end{array}$ \\
\hline \multirow[t]{2}{*}{ Constant) } & $\begin{array}{l}3370.5 * * * \\
(20.17)\end{array}$ & $\begin{array}{c}0.000000228 * * * \\
(13.85)\end{array}$ & $\begin{array}{c}- \\
0.00000228 * * * \\
(-7.18)\end{array}$ & $\begin{array}{c}- \\
0.00000125 * * * \\
(-5.75)\end{array}$ & $\begin{array}{c}- \\
0.000000857 * * * \\
(-2.70)\end{array}$ \\
\hline & 0.0718 & 0.0505 & 0.3578 & 0.2855 & 0.1855 \\
\hline $\mathrm{N}$ & 250 & 250 & 250 & 250 & 250 \\
\hline
\end{tabular}

The results indicate that for the dummy variable in model 1 , the results are positive and significant which implies that after the information disclosure system is implemented, the trading volume in the first minute increased significantly. Furthermore, S\&P500 is found to be having insignificant influence on the trading volume. The dummy variable coefficient in second model is negative showing decrease in market liquidity after the implementation of the market information disclosure system. In third, fourth, and fifth model, the trading volume and liquidity are control variables and results are positive which shows that as the trading volume increases, the volatility increases. Higher volatility is found to be associated with higher liquidity.

Table 7

Empirical Results of the Futures Market

\begin{tabular}{|c|c|c|c|}
\hline $\begin{array}{c}\text { First } 5 \text { minutes of } \\
\text { trading } \\
\end{array}$ & $\begin{array}{l}\text { Market } \\
\text { quality }\end{array}$ & $\begin{array}{l}\text { Coefficient before the factors are } \\
\text { controlled }\end{array}$ & $\begin{array}{c}\text { Coefficient after the factors are } \\
\text { controlled }\end{array}$ \\
\hline \multirow{5}{*}{$\begin{array}{l}\text { First } 1 \text { minute of } \\
\text { trading }\end{array}$} & Volume & + & + \\
\hline & Liquidity & + & + \\
\hline & Volatility & +-- & +-- \\
\hline & Volume & + & + \\
\hline & Liquidity & + & + \\
\hline
\end{tabular}


The above table shows the empirical results after the implementation of the information disclosure in the future market. The result shows that for liquidity and trading volume, there is significant increase after first 1 or 5 minutes after market opens. We observed small increase in the volatility estimated using the classic estimator whereas for Garman-Klass and Parkinson estimator, it decreased slightly.

\section{CONCLUSION}

The study was about testing the relationship between market information disclosure system and market quality. The study found that for future market, the trading volume and market liquidity is increased significantly after the information disclosure system is implemented but before the market opens. Furthermore, we observed increase in volatility as the trading volume increased. We also compared results for the period of 1 minute after the market opens and found consistent results similar to the 5 minutes time period. Overall, our results shows that as the information disclosure system is implemented in the Indonesian stock exchange, it improved the market transparency and enhanced information efficiency.

\section{References}

Alexakis, P. (2007). On the effect of index futures trading on stock market volatility. International Research Journal of Finance and Economics, 11(7), 7-28.

Amihud, Y. (2002). Illiquidity and stock returns: cross-section and time-series effects. Journal of Financial markets, 5(1), 31-56.

Amihud, Y., \& Mendelson, H. (1886). Asset pricing and the bid-ask spread. Journal of Financial Economics, 17(2), 223-248.

Bessembinder, H., \& Seguin, P. J. (1883). Price volatility, trading volume, and market depth: Evidence from futures markets. Journal of Financial and Quantitative Analysis 28(1), 21-38.

Bloomfield, R., \& O'Hara, M. (1888). Market transparency: Who wins and who loses? Review of Financial Studies, 12(1), 5-35.

Chou, R. Y., Chou, H., \& Liu, N. (2010). Range volatility models and their applications in finance. In Handbook of Quantitative Finance and Risk Management. Springer US.

Dia, M., \& Pouget, S. (2005). Liquidity Formation and Preopening Periods in Financial Markets. Working Paper, University of Toulouse I Capitole.

Easley, D., \& O'hara, M. (1882). Time and the process of security price adjustment. The Journal of Finance, 47(2), 577-605.

Easley, D., \& O'hara, M. (2004). Information and the cost of capital. The Journal of Finance, 58(4), 1553-1583.

Hsieh, W. L. G. (2002). Market integration, price discovery, and information transmission in Taiwan index futures market. Journal of Financial Studies, 10(3), 1. 
Hsu, C.H., \& Lee, H.C. (2014). Insider trading and information revelation with the introduction of futures markets. Economic Modelling, 43, 173-182.

Jiang, L., \& Kryzanowski, L. (1887). Trading activity, quoted liquidity, and stock volatility. Multinational Finance Journal, 1(3), 188-227.

Kawaller, I. G., Koch, P. D., \& Koch, T. W. (1887). The temporal price relationship between S\&P 500 futures and the S\&P 500 index. The Journal of Finance, 42(5), 1308-1328.

Koski, J. L., \& Michaely, R. (2000). Prices, liquidity, and the information content of trades. Review of Financial Studies, 13(3), 658-686.

Lyons, R. K. (1883). Optimal transparency in a dealership market with an application to foreign exchange (No.w4467). National Bureau of Economic Research.

Madhavan, A. (1886). Security prices and market transparency. Journal of Financial Intermediation, 5(3), 255-283.

Medrano, L. A., \& Vives, X. (2001). Strategic behavior and price discovery. RAND Journal of Economics, 221-248.

O'Hara, M. (2001). Designing markets for developing countries. International Review of Finance, 2(4), 205-215.

O'hara, M. (1885). Market microstructure theory (Vol. 108). Cambridge, MA: Blackwell.

Sankaraguruswamy, S., Shen, J., \& Yamada T. (2013). The relationship between the frequency of news release and the information asymmetry: The role of uninformed trading. Journal of Banking \& Finance, 37, 4134-4143.

Wang, G. H., \& Yau, J. (2000). Trading volume, bid-ask spread, and price volatility in futures markets. Journal of Futures Markets, 20(10), 843-870. 